\title{
The Role of Organizational Commitments Mediates The Effect of Competence on Employee Performance in PT. Bali Tangi Spa Production
}

\author{
I Ketut Suantara*, Putu Ngurah Suyatna Yasa and Ni Wayan Sitiari \\ Magister of Management, Postgraduate Program, Universitas Warmadewa, Denpasar, Bali- \\ Indonesia \\ *ik.suantara2014@gmail.com
}

\begin{tabular}{|c|}
\hline Published: $30 / 03 / 2020$ \\
\hline How to cite (in APA style): \\
\hline $\begin{array}{l}\text { Suantara, I. K., Yasa, P. N. S., \& Sitiari, N. M. (2020). The Role of Organizational Commitments Mediates The Effect of } \\
\text { Competence on Employee Performance in PT. Bali Tangi Spa Production. Jurnal Ekonomi dan Bisnis Jagaditha, 7(1), 53- } \\
\text { 64. doi: https://doi.org/10.22225/ii.7.1.1653.53-64 }\end{array}$ \\
\hline
\end{tabular}

\begin{abstract}
Business development and competition will continue to increase from time to time following the development of information technology, so each company must continue to be creative and innovate by continuously improving the quality of its human resources. Human resources are one of the most important assets in a company or organization, as sophisticated and as complete as any other aspect of the organization but without the support of competent human resources, the organization will not operate well. This study aims to examine the effect of competence on employee performance, the effect of competence on organizational commitment, the effect of organizational commitment on employee performance and the role of organizational commitment mediating competence on employee performance. The method of determining the sample in this study uses a census method in which all employees totaling 37 people are sampled at PT. Bali Tangi Spa Production, Denpasar, Bali and data processing using Partial Least Square (PLS) analysis technique version 2.0. The results of the study stated that competence had a positive and significant effect on organizational commitment, competence had a positive and not significant effect on employee performance, organizational commitment had a positive and significant effect on employee performance and company commitment played a partial mediation in mediating competence on employee performance. In general, employees have a very good performance but management is advised to provide training, especially in the use of work equipment and also provide deeper motivation to increase organizational commitment.
\end{abstract}

Keywords: Competence, Organizational Commitment and Employee Performance

\section{INTRODUCTION}

One of the things that companies can take to be able to survive in fierce competition is to maximize their human resources. Human resource planning can be done properly and correctly if the planners know what and how human resources are. The statement indicates how important it is to have high-quality employees to support the company in carrying out the vision, mission and goals of the organization where it works. PT. Bali Tangi Spa Production is a manufacturer of traditional spa and cosmetics based on local wisdom using ingredients from plants in Bali in particular and in Indonesia in general. The company is endeavoring to maintain and develop quality products and to be able to compete in the business arena of spa and cosmetics made from natural herbs at the international level Bali Tangi must be supported by employees who have high performance.

Employee performance according to Hasibuan (2007) is a result of work achieved by a person in carrying out the tasks assigned to him based on skill, experience, and sincerity as well as time. (Gupta, 2013) explains that companies need employees who are able to work better and faster, so they need employees 
who have high performance (Job

Performance). Besides that, Alfi et al. (2015)

in its scientific research related to organizational commitment to the performance of employees at PT Bank Mandiri Tbk. The Cirebon Area concludes that organizational commitment has a positive influence on employee performance. Thus, the authors can analyze that employee performance can be influenced by organizational commitment.

Additionally, organizational commitment according to (Mathis \& Jackson, 2006) is the level of trust and acceptance of the workforce towards the goals of the organization and has a desire to remain in the organization which is ultimately reflected in the statistics of absenteeism and in and out of the workforce. While (Greenberg \& Baron, 2003) stated that organizational commitment is the degree to which employees are involved in their organization and wish to remain members, which contains an attitude of loyalty and willingness of employees to work optimally for the organization where the employee works.

Employee performance is also influenced by competence as stated by George Klemp in (Edison, Anwar, \& Komariyah, 2016), namely competency is a characteristic that underlies someone who produces an effective job and / or superior performance. Meanwhile, (Spencer Jr \& Spencer, 2007), defines competency is the underlying characteristics of a person and relate to the effectiveness of individual performance on the job. The opinions of the experts above are empirically proven by (Malau, Barasa, \& Sumali, 2019) in his research entitled Effect of Competence and Ship Crew Discipline on Performance PT. Myclin Express Offshore states that competence has a positive and significant effect on performance.

Based on the opinion of several experts and also the results of scientific research that has been carried out by several people above, it is necessary to conduct research back at PT. Bali Tangi Spa Production because there are employee performance indicators that are not optimal. The less than optimal employee performance indicators are reflected in the fluctuating level of absenteeism and below the standard provisions for several months from September 2018 to October 2019. Based on attendance data for the past fourteen months, it shows that the absenteeism of PT. Bali Tangi Spa Production is fluctuating from month to month. The average absentee level of PT. Bali Tangi Spa Production over the month of
September 2018 until October 2019 amounted to $7.01 \%$. The level of attendance exceeds the company's maximum absentee level of $5 \%$. The level of absence that exceeds the established tolerance standards can interfere with the company's operational activities which can have an impact on the low performance of employees as well as company performance.

In spite of that problems, it can be defined purpose of this study is to analyze and explain the effect of the competence of the commitment of the organization, the effect of the competence of the employee's performance, the effect of the commitment the organization to employee performance, analyze and explain the role of commitment to the organization in mediating the effect of competence on employee performance at PT. Bali Tangi Spa Production.

\section{The performance}

According to (Gibson, 1997) defines performance as a result of work related to organizational goals, such as quality, efficiency, and other work effectiveness criteria. Performance is also the result that has been achieved by someone who is related to the tasks and roles they do. According to (Hersey \& Blanchard, 1993), performance is defined as a function of motivation and ability. So that in order to complete a task or job, a person must have a certain level of ability and degree of willingness. The ability and willingness of a person is not effective to do a thing without prior understanding of what will be done or done and how to do it. (Sentono, 1999) argues that performance is the work that can be achieved by a person or group of people in an organization, in accordance with their respective authorities and responsibilities in order to achieve the organization's objectives legally, not violating the law and in accordance with moral and ethical. From some of the expert opinions it can be said that employee performance is the result of work produced by employees or actual behavior that is displayed from a number of efforts made at work in accordance with their role in the organization.

According to Bernardin and Russel in (Sutrisno, 2011) performance appraisal is a way to measure the contribution of employees in the organization where they work. Bernardin Russel filed six primary criteria that can be used to measure the performance such as, among others: 1) The quantity of work, 2) quality of the work, 3) Accuracy of Time, 4) Effectiveness, 5) Independence, 
Commitment to work.

\section{Competence}

According to Watson Wyatt in (Achmad, 2003) states competence is the combination of skills, knowledge, and behavior that can be observed and applied critical to the success of an organization and work performance and personal contribution of employees of the organization. According to Boyatzis in (Hutapea \& Thoha, 2008) stated that competence is a capacity that exists in a person which can make that person can fulfill what is required by work in an organization so that the organization is able to achieve the desired results.

Of the several competency definitions above, it is generally stated that competency is the ability possessed by an employee consisting of aspects of knowledge, skills and attitudes in accordance with company rules or policies in order to be able to carry out tasks and responsibilities to achieve the company's strategic goals. Some of the aspects contained in the concept of competence according to Gordon in (Sutrisno, 2011) as follows: 1) knowledge, 2) undersatnding, 3) Skills, 4) values, 5) behavior, 6) interest.

\section{Organizational Commitment}

According to Meyer and Allen in (Soekidjan, 2009), commitment can also mean an individual's strong acceptance of organizational goals and values, and individuals strive and work and have a strong desire to stay afloat in the organization. (Dessler, 2013) defines employee commitment to the company or organization relationship between employees and companies / organizations that are employee orientation in the company so that they are willing to contribute their energy and commit themselves through activities and involvement in the company to achieve company goals. Understanding organizational commitment is the degree to which employees are involved in the organization and wishes to remain members, which contains an attitude of loyalty and willingness of employees to work optimally for the organization where the employee works (Greenberg \& Baron, 2003). The opinion of (Meyer, Allen, \& Smith, 1993) suggested indicators of organizational commitment can be divided into three as follows: 1) Affective commitment, 2) Continuance commitment, 3) Normative commitment.

\section{CONCEPTS AND HYPOTHESES}

The conceptual framework is a logical relationship from the theoretical foundation and empirical study described in the previous section. Based on the problem formulation of the mindset, in this study the independent variables are competence (X1), organizational commitment (Y1) and employee performance dependent variables (Y2). In accordance with the number of variables identified, a conceptual framework is then arranged that explains the relationship between variables in this study can be described as follows:



Figure 1

Theoretical framework

\section{Effect of Competence on Organizational Commitment}

(Goel, Sahai, Vinaik, \& Garg, 2019) stated that the results of the regression analysis stated that the impact of competence on teaching commitment had a significant positive effect on ongoing commitment in his research. (Marjito, 2014) revealed that teacher competence had a positive and significant effect on organizational commitment in his research. Likewise, (Khoreva, Vaiman, \& Zalk, 2017) stated that talent management has a positive influence on commitment to competence. Another case with (Izzati, Suhariadi, \& Hadi, 2016) that self-competence has considerable influence on affective commitment. Other research by (Yuliantini, Astika, \& Badera, 2017) with his research HR competencies has a positive effect on organizational commitment, in his research. Based on the above studies, the hypothesis can be formulated as follows:

H1: Competency positive and significant effect on the commitment of the organization.

\section{Effect of Competence on Employee Performance \\ Research conducted by (Khattak, Mustafa, Rehman, \& Khattak, 2016) in his research which took the theme of states competence has a positive and significant effect on company performance in Pakistan. While (Tehseen, Qureshi, \& Ramayah, 2018)}


argued that competence has a positive and significant effect on company performance among Chinese entrepreneurs as stated in his research. (Meswantri \& Awaludin, 2018) concluded that employee placement of transformational leadership, competence and employee involvement either partially or simultaneously has a positive and significant effect on employee performance. This conclusion is also supported by the results of (Trismiyanto, Sule, Joeliaty, \& Yunizar, 2018) stated that competence in the field of entrepreneurship has a positive and significant effect on performance. Likewise, the results of (Alexandri, Pragiwani, \& Yuswardi, 2019) revealed that competence had a positive and significant effect on performance at the Criminal Investigation Police and (Malau et al., 2019) in his research stated competence had a positive and significant effect on performance. Based on the above research the following hypotheses can be formulated:

H2: Competence has a positive and significant effect on employee performance.

\section{Effect of Organizational Commitment on Employee Performance}

The results of scientific research conducted by (Carmeli \& Freund, 2004) conducting a research study stated that the factors of affective commitment, continuance commitment and career commitment will be positively related to employee performance through job satisfaction. (Wang, Jiang, Weng, \& Wang, 2019) in his research stated that the formulation of organizational policies and strategies as well as work commitments in other functional human resource processes, such as guidance and career development guidelines, can help improve employee performance, which ultimately benefits the organization. (Fauzan \& Sumiyati, 2015) in their scientific research concluded that organizational commitment has a positive influence on employee performance. (Setyaningrum, Setiawan, Surachman, \& Irawanto, 2017) conducted a study of 90 respondents at the senior manager level, assistant managers in the Vegetable Hatchery Industry in Indonesia concluded that organizational commitment significantly affected employee performance. Based on the above studies, the hypothesis can be formulated as follows:

H3: Organizational commitment has a positive and significant effect on employee performance.

Effect of organizational commitment in

\section{mediating Competence on Employee Performance}

The results of research conducted by (Rantesalu, Mus, Mapparenta, \& Arifin, 2016) concluded that competence has a positive and significant effect on employee performance mediated by organizational commitment. (Kurniasari, Thoyib, \& Rofiaty, 2018) in their research stated that organizational commitment through mediation test results can mediate the effect of competence on nurse performance. While the research conducted by (Saputri \& Muhsin, 2018) organizational commissions have a positive influence indirectly through organizational commitment to the performance of village officials. Based on the results of several studies above, the following hypotheses can be made:

H4: Organizational commitment mediates the effect of competence on employee performance.

\section{METHOD}

This research was conducted on all employees of PT. Bali Tangi Spa Production Denpasar, amounting to 37 people. The sampling method using the method of NonProbability Sampling is sampling $\mathrm{j}$ enuh or census method which is a sampling technique when all members of the population used as a sample.

The data collection technique is by observation, study the documentation and dissemination of my e sioner followed by validity and reliability. Data analysis method used in this research is SEM (Structural Equation Modeling) analysis based on da variance component, namely PLS (Partial Least Square). The results of the analysis are interpreted and discussed, so that in the end it can be concluded the results of the study and given advice on the problem.

\section{Data Collection Instruments}

In this study, the instrument used was in the form of a questionnaire, namely the collection of research data consisting of several written statements addressed to respondents regarding the relationship of the variables studied.

\section{Test Validity of Instruments}

Ach validity test is used to measure the validity of a questionnaire, (Ghozali, 2011). A questionnaire is said to be valid if the questions on the questionnaire are able to reveal something that will be measured by the questionnaire. So validity is measuring 
whether the questions in the questionnaire that have been made really can measure what you want to be measured. According (Sugiyono, 2012) validity testing can be done using product moment correlation. If the correlation coefficient is equal to 0.30 or greater (at least 0.30 ) then the instrument is declared valid, and invalid if the coefficient is smaller than 0.30 . In determining whether an item is appropriate or not, a significance coefficient correlation test is usually carried out at the 0.05 significance level, meaning that an item is considered valid if it has a significant correlation to the total score.

\section{Instrument Reliability Test}

Reliability test is a tool to measure a questionnaire which is an indicator of the variable or construct of (Ghozali, 2011). A questionnaire is said to be reliable or reliable if a person's answer to a statement is consistent or stable from time to time. Respondents' answers to these questions are said to be reliable if each question is answered consistently or the answers should not be random because each question wants to measure the same thing. If the answer to this indicator is random, it can be said that is not reliable (Ghozali, 2011). Reliability measurement can be done with one shot or measurement just once. Here the measurement is only once and then the results are compared with other questions or measure the correlation between the answers to questions. The tool for measuring reliability is Chronbach's Alpha. A variable is enriched reliable, if the results a> $0.60=$ reliable and Results a $<0.60=$ not reliable (Ghozali, 2011).

There are two types of research methods used in this study, namely descriptive analysis and inferential analysis can be explained as follows. Firstly, in this study using descriptive analysis to describe the characteristics of research respondents seen from several research variables concerning: respondents' perceptions of employee competencies, organizational commitment and employee performance. Descriptive analysis functions to describe or give a description of the object under study through data samples or populations as they are, without conducting analysis and making conclusions that apply to the public (Sugiyono, 2012).

Secondly, inferential analysis is used to analyze the relationship between variables in this study, including competencies, organizational commitment and employee performance. In analyzing the influence of exogenous variables with endogenous variables in this study using the statistical method of Partial Least Square (PLS). Because this method is known to be very practical and does not require many assumptions including the assumption of a normal distribution. PLS is a variant-based Structural Equity Model (SEM) that can simultaneously conduct measurement model testing as well as structural model test. The measurement model is used to test the validity and reliability, while the structural model is used to test causality. Hypothesis testing with predictive models (Jogiyanto \& Abdillah, 2009).

\section{RESULTS AND DISCUSSION}

\section{Validity Test of Research instruments}

According to (Sugiyono, 2004), a valid instrument means that the measuring instrument used to obtain data (measuring) is valid. Valid means that the instrument can be used to measure what should be measured. The validity test was carried out on instrument items, using the Pearson product moment correlation method, i.e. the item / indicator was said to be valid if it had a correlation coefficient $\geq 0.30$ and statistically significant $p$ value $<0.05$ or t statistic $>1.96$. After testing the validity of the research instruments showed that all correlations between items with the total construct score showed a number $>0.30$ means that it showed valid results.

\section{Reability Test of Research Instruments}

Reliable instruments are carried out on constructs, instruments that when used several times to measure the same object, will produce the same data. A rubber length measuring instrument is an example of an unreliable / consistent instrument. Reliability test method is used Cronbach's Alpha (CR), item / indicator is said to be reliable if the value of Cronbach's Alpha $\geq 0.70$. The instrument reliability test results in Table 5.6 below show that Cronbach's Alpha $>0.70$ means that the reliability of all research variables is categorized as good and accepted.

\section{Descriptive Analysis}

Description of the variables used to describe each variable seen from the frequency distribution of respondents' answers to the statement of the variables studied for the interpretation of that survey, used five classification the interval calculation as follows (Umar, 2005): 


$$
\begin{aligned}
\text { terval }=\frac{m(n-1)}{n \cdot m} & \\
& =\frac{37(5-1)}{5.37} \\
& =\frac{148}{185}=0,8
\end{aligned}
$$

Note: $\mathrm{m}=$ number of respondents, $\mathrm{n}=$ number of scales

So interpretation above the average score of the variables with a positive response (favorable) is with the following criteria: value from 1.00 to $1.80=$ Very good, value from 1.81 to $2.60=$ Not good, use values $2,61-3,40$ $=$ Not Good, Value 3,41-4,20 = Good, Value 4,21-5,00 = Very good.

Description analysis is used to explain the respondent's response to the questions in the questionnaire. This analysis is to analyze the data collected and used to identify the characteristics of each variable that will be used as material for analysis.

\section{Inferential Analysis}

Inferential analysis in scientific research was carried out by the Partial Least Square (PLS) method, used to analyze the influence of exogenous variables with endogenous variables in this study. The PLS process in this study goes through the following stages.

\section{Evaluation of Measurement Model (Measurement Model / Outer Model)}

In connection with the indicators that form latent variables in this study are reflexive, then the evaluation model measurement ( measurement model / outer model ), to measure the validity and reliability of these indicators are: a) convergent validity , b) discriminant validity, and c ) composite reliability and Cronbach Alpha, can be described in the following explanation.

\section{Convergent Validity}

Convergent validity is a criterion in measuring the validity of indicators that are reflexive. This evaluation is done through an examination of the outer loading coefficient of each indicator of its latent variable. An indicator is said to be valid, if the outer loading coefficient is between $0.60-0.70$, but for analyzes whose theories are unclear, an outer loading of 0.50 is recommended (Ghozali, 2011), and is significant at an alpha level of 0.05 or t- statistics of 1.96 .

The calculation results regarding the outer loading value in Table 5.10 show that all indicators have met the valid requirements based on the convergent validity criteria, namely the outer loading value $>0.50$ and statistically significant. These results can be seen in Figure below.



Figure 2

Outer Loading Estimation Results and Path Analysis

While the results of calculations regarding the results of the significance test (boothstrapping) before the reconstruction can be seen in Figure below.

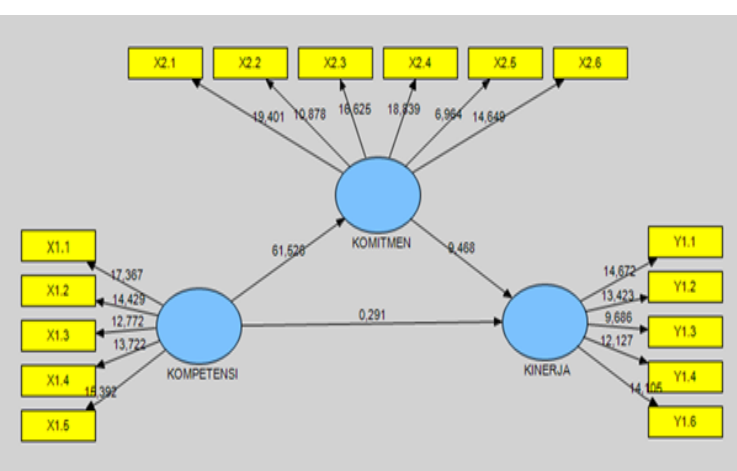

Figure 3

Boothstrapping (Test Statistics)

\section{Discriminant Validity}

The measurement of the validity of the indicators that make up the latent variable can also be done through discriminant validity by looking at the value of AVE and AVE. The indicator is considered valid if the AVE value of each construct is $>0.50$ and the value of AVE is all constructs $>$ the correlation value between variables (Lathan \& Ghozali, 2012). The test results show that the value of $\sqrt{ }$ AVE of each construct ranges from 0.82 to 0.92 , greater than the correlation value between constructs, the magnitude of 0.77 to 0.91 , and the value of AVE of each construct $>0.50$, namely ranging from 0.70 to 0.94 , so it is declared valid based on discriminant validity criteria.

\section{Composite Reliability and Cronbach's Alpha}

A measurement can be said to be reliable, if the composite reliability and Cronbach's alpha have a value greater than 0.70 . 
Composite reliability and Cronbach's alpha is a measure of reliability among indicator blocks in the research model. The results showed that the composite reliability value of each construct had shown a value greater than 0.70 so that it met the reliable requirements based on the composite reliability criteria. In terms of Cronbach's Alpha values, all constructs do not have index values greater than 0.70 , so both criteria have met the construct reliability requirements.

\section{Evaluation of Structural Model/Inner Model}

Evaluation of structural models (Structural Model / Inner Model) is a measurement to evaluate the level of accuracy of the model in the overall research, which is formed through several variables along with the indicators. In evaluating this structural model, several approaches will be carried out including: a) R-Square $\left(\mathrm{R}^{2}\right)$, b) Q-Square Predictive Relevance $\left(\mathrm{Q}^{2}\right)$, and c) Goodness of Fit (GoF), each of which can be explained as following:

\section{Evaluation of Structural Models through $R$ - Square $\left(R^{2}\right)$ \\ $\mathrm{R}$-Square $\left(\mathrm{R}^{2}\right)$ can indicate the strength of} the effect caused by the dependent variable to the independent variables. R-Square $\left(\mathrm{R}^{2}\right)$ also can indicate the strength of a research model. According to Chin (Lathan \& Ghozali, 2012), the value of R-Square $\left(\mathrm{R}^{2}\right)$ of 0.67 relatively robust models, $\mathrm{R}$-Square $\left(\mathrm{R}^{2}\right)$ of 0.33 moderate models, and R-Square $\left(\mathrm{R}^{2}\right)$ equal to 0,19 classified as a weak model. The research result shows that the value of $\mathrm{R}^{2}$ performance of 0.70 , based on criteria Chin (Lathan \& Ghozali, 2012), then the model including criteria powerful model, the meaning is the variation of competence and commitment to the organization is able to explain variations in performance by $70 \%$ percent, the remaining $30 \%$ percent is explained by variations of other variables outside the analyzed model. Whereas commitment has an R-square value of 0.83 or includes a strong model, meaning that variations in competence can explain variations in organizational commitment that is equal to $83 \%$ percent and the remaining $17 \%$ is explained by variations outside the model.

Evaluation of Structural Models through QSquare Predictive Relevance $\left(Q^{2}\right)$

Q-Square Predictive Relevance $\left(\mathrm{Q}^{2}\right)$ is a measure of how well the observations made give results to the research model. Q-Square Predictive Relevance $\left(\mathrm{Q}^{2}\right)$ values range from 0 (zero) to 1 (one). The closer to 0 the value of $Q$ -Square Predictive Relevance $\left(\mathrm{Q}^{2}\right)$, gives a clue that the research model is getting better, while the opposite is getting away from 0 (zero) and getting closer to the value of 1 (one), this means the better the research model. The criteria for strength or weakness of the model are measured based on Q-Square Predictive Relevance $\left(\mathrm{Q}^{2}\right)$ according to Lathan and Ghozali (2012) are as follows: 0.35 (strong model), 0.15 (moderate model), and 0.02 (model weak). The Q-Square formula is: $Q^{2}=$ $1-\left(1-\mathrm{R}_{1}^{2}\right)\left(1-\mathrm{R}_{2}^{2}\right)$.

The value of $Q$-Square is $=1-\left(1-\mathrm{R}_{1}{ }^{2}\right)$ $\left(1-\mathrm{R}_{2}{ }^{2}\right)=1-(1-0.70)(1-0.83)=1-0.051$ $=0.95$, based on this result, the estimation result model is included in the strong criteria, meaning that $95 \%$ of variations in endogenous constructs can be predicted by variations in exogenous constructs.

\section{Evaluation of Structural Models through Goodness of Fit (GoF)}

Goodness of Fit (GoF) is a measurement of the accuracy of the overall model (global), because it is considered a single measurement from the measurement of the outer model and measurement of the inner model. Measurement values based on Goodness of Fit (GoF) have a range of values between 0 (zero) to 1 (one). Value Goodness of Fit (GoF) is getting closer to 0 (zero), shows a model of the less good, otherwise getting away from 0 (zero) and approaching 1 (one), then the model is getting better. The criteria of strength and weakness of the model based on the measurement of Goodness of Fit (GoF) according to Lathan and Ghozali (2012: 88), are as follows: 0.36 (GoF large), 0.25 (GoF medium), and 0.10 (GoF small). (Tenenhaus et al., 2004: 175). The results of calculations with GoF shows the value of the average $R{ }^{2}$ of 0.76 while the average Communality of 0.95 , then the GoF value of $\sqrt{ } \mathrm{AR}^{2} *$ A.Com /A.rho $=\sqrt{ } 0.76 *$ $0.95=\sqrt{ } 0.72=0.85$. This means that the global model is a good predictive (large).

\section{Path Analysis and Hypothesis Testing}

The expected path analysis and hypothesis testing is Ho rejected or sig $<0.05$ or t-statistic value $>1.96$ with a level of significance of 0.05 . 
Table 1

Path Analysis and Testing Statistics

\begin{tabular}{ccccccc}
\hline Construct & $\begin{array}{c}\text { Original } \\
\text { Sample (O) }\end{array}$ & $\begin{array}{c}\text { Sample } \\
\text { Mean } \\
(\mathrm{M})\end{array}$ & $\begin{array}{c}\text { Standard } \\
\text { Deviation } \\
(\text { STDEV) }\end{array}$ & $\begin{array}{c}\text { Standard } \\
\text { Error } \\
(\text { STERR) }\end{array}$ & $\begin{array}{c}\text { T } \\
\text { Statistics } \\
(\mid \mathrm{O} / \\
\text { STERR } \mid)\end{array}$ & Criteria \\
\hline $\begin{array}{c}\text { Commitment }-> \\
\text { Performance }\end{array}$ & .81 & .82 & 0.09 & 0.09 & 9.47 & Significant \\
$\begin{array}{c}\text { Competence }-> \\
\text { Performance }\end{array}$ & 0.03 & 0.02 & .10 & .10 & 0.29 & Not significant \\
$\begin{array}{c}\text { Competence -> } \\
\text { Commitment }\end{array}$ & .91 & .91 & 0.01 & 0.01 & 61.53 & Significant \\
\hline
\end{tabular}

\section{Source: Research Results}

Table 1 shows:

a. Commitment to the organization influential positi $f$ of 0.81 on the performance, and the relationship is significant at the 0.05 level for T-Statistics value greater than 1.96, which is equal to 9.47 .

b. Competence has positive effect on the performance of 0.03 , and the relationship is not significant at the 0.05 level with a $t$ value of 0.29 .

c. Competence has positive effect amounted to 0.091 against the commitment and the relationship is significant at the 0.05 level with a $t$ value of 61.53 is greater than the value of the T-table is 1.96 .

\section{The effects of mediation analyzed include direct analysis and indirect effect analysis}

In this study using the examination method. Examination method by conducting two analyzes, namely analysis involving mediation variables and analysis without involving mediation variables. The method of checking mediation variables with the coefficient difference approach is carried out as follows:

a. examine the direct effect of Independent Variables on Dependent Variables on the model by involving mediating variables,

b. examine the effect of the Independent Variable on Dependent Variables on the model without involving mediating variables,

c. examine the effect of the Independent Variable on Mediation Variables, and

d. examine the effect of the Mediation variable on the Dependent variable.

Determination of the mediating role of a variable is based on the following provisions which refer to the inspection method as described above:

a. If (c) and (d) are significant, and (a) insignificant, then the intervening variable is said to be a complete mediation variable.

b. If (c) and (d) are significant and (a) also significant, where the coefficient of (a) is smaller (down) than (b) then the intervening variable is said to be a partial mediation variable.

c. If (c) and (d) are significant and (a) also significant, where the coefficient of (a) is almost the same as (b) then the intervening variable is said not to be a mediating variable.

d. If either (c) or (d) or both are insignificant then they are not said to be mediating variables (Solimun, 2011; Hair Jr, Black, Babin, \& Anderson, 2010).

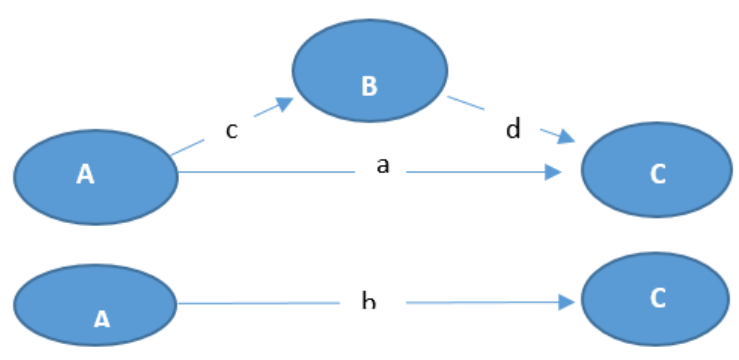

Figure 4

Theoretical Role of Mediation

Based on the results of calculations, the mediation role test can be seen in Figures below.




Figure 5

The Role of commitment in mediating competence on performance (Indirect Effect)

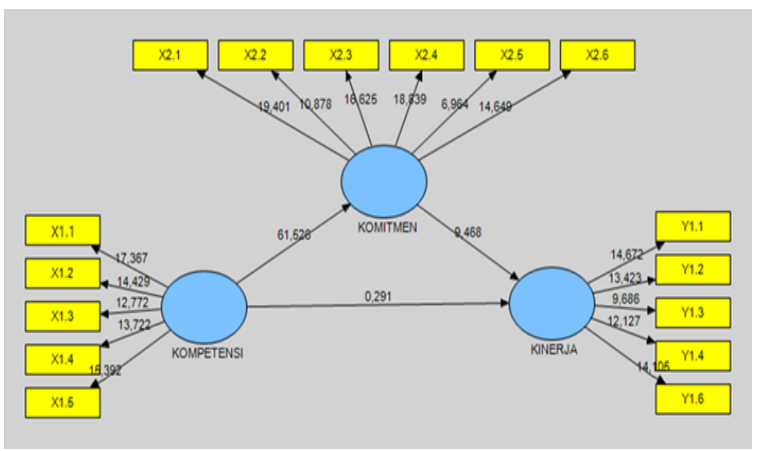

Figure 6

Statistical Test the Role Commitment in Mediating Competency on performance (Indirect Effect)

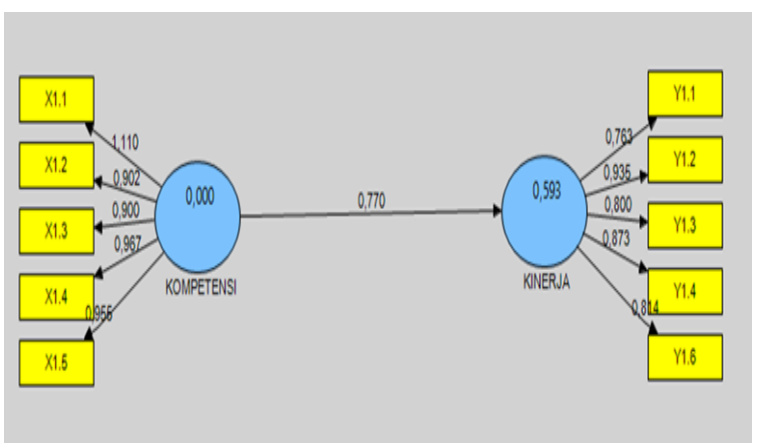

Figure 7

Direct Relationship between Competence and Performance

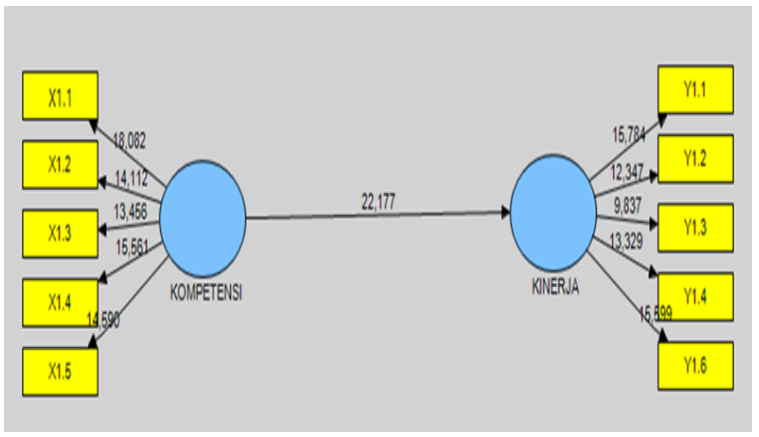

Figure 8

Test Statistics Direct Relationship between Competence and Performance

Based on Figure on top, it turns out that organizational commitment is a perfect mediation (full mediation) between competencies and employee performance, because the indirect relationship between competence and employee performance is not significant, while the indirect relationship between organizational commitment and employee performance is significant.

\section{Discussion}

Influence of competence on organizational commitment at PT. Bali Tangi Spa Production

Based on the results of competency testing positive and significant effect on organizational commitment. These results indicate that the better the competencies possessed by employees, the organizational commitment of employees at PT. Bali Tangi Spa Production is also getting higher, according to what was stated by Klemp in (Edison et al., 2016), namely competency is an underlying characteristic of someone who produces effective work and / or superior performance. Judging from the average value of indicators on this competency variable there are criteria of very agree, this result shows that employees have high competence both from the factors of knowledge, skills, understanding, attitudes and values or standards of behavior needed when doing work. From the results of this study, there are also 2 (two) indicators with scores below the average, namely the ability to use work equipment with agreed criteria and indicators of adherence to rules with agreed criteria. If related to the characteristics of respondents according to tenure, the tenure of 5 to 10 years or more than ten years is more dominant than employees who have tenure under 5 years. This period of service can certainly have an effect on an employee's competence, the longer the work period the higher the level of competence. Employees who have a working period of under 5 years need to be given additional training so that their competencies are higher and the same as more senior competencies.

Thus the hypothesis in this study which states that competence has a positive and significant effect on organizational commitment at PT. Bali Tangi Spa Prduction is proven right. The results of this study are in line with previous research conducted by (Marjito, 2014), (Khoreva et al., 2017), (Izzati et al., 2016) and (Yuliantini et al., 2017) which shows that competence has a positive and significant effect on organizational commitment.

Influence of competence to employee performance at PT. Bali Tangi Spa Production

Based on the results of testing regarding the effect of competence on employee performance at PT. Bali Tangi Spa Production, shows that competence has a positive effect on employee performance but not significantly. This result states that although the higher the competence, the higher the performance of employees at PT. Bali Tangi Spa Production but not significant, the intention is that the higher the competence the higher the employee's performance but there is still one other indicator that is not optimal. In 
accordance with the results of this study competency indicators include quality, quantity, attitudes and interests are very good but the problem of timeliness is not optimal, the level of attendance is still relatively high but in general their performance is very good in carrying out their duties and responsibilities. The results of this study are not in line with that expressed by Wyatt in (Achmad, 2003) states competence is the combination of skills, knowledge, and behavior that can be observed and applied critical to the success of an organization and achievement work and employee's personal contribution to the organization. Thus disagrees with the results of research conducted by (Khattak et al., 2016), (Tehseen et al., 2018), (Meswantri \& Awaludin, 2018), (Alexandri et al., 2019), (Malau et al., 2019) which produced a study that variable competence positive and significant effect on employee performance.

The effect of organizational commitment on employee performance at PT. Bali Tangi Spa Production

Based on the results of testing on the effect of organizational commitment on employee performance shows that organizational commitment has a positive and significant effect on employee performance. The results of this study prove that organizational commitment increases the performance of the employees of PT. Bali Tangi Spa Production also increased significantly.

From the characteristics of respondents according to tenure, the results of this study describe respondents in this study with tenure less than 5 years as many as 16 people or 43 percent, with tenure between 5 to 10 years as many as 15 people or 41 percent and those with more than ten years of service 10 years as many as 6 people or 16 percent. Thus of the total number of employees, employees with tenure of 5 (five) years and above are greater than those under five years. This illustrates that most employees want to remain members of the company, want to stay afloat and have a sense of ownership and responsibility for the survival of the company.

The results of this analysis are consistent with what was stated by Meyer and Allen in (Soekidjan, 2009) that commitment can also mean strong acceptance of individuals against organizational goals and values, and individuals strive and work and have a strong desire to remain in the organization. The results of this study were also supported by previous studies including: (Carmeli \& Freund, 2004), (Setyaningrum et al., 2017), (Wang et al., 2019), (Fauzan \& Sumiyati, 2015) with the results of the study that organizational commitment consisting of affective commitment, ongoing commitment and normative commitment has a positive and significant impact on employee performance.

\section{The role of organizational commitment in mediating competence on employee} performance at PT. Bali Tangi Spa Production

Based on the criteria of (Hair Jr et al., 2010), from the results of this study it turns out that organizational commitment is a perfect mediation (full/complete mediation) between competency variables and employee performance. From the results of testing between variables, the result is the relationship between competence with significant organizational commitment, the relationship between organizational commitment and significant employee performance and the relationship between competence and employee performance is not significant. This means that organizational commitment perfectly mediates between the relationship of competence to employee performance at PT. Bali Tangi Spa Production.

The results of this study are in line with the results of previous studies conducted by (Rantesalu et al., 2016), (Kurniasari et al., 2018) and (Saputri \& Muhsin, 2018) which states that organizational commitment plays a positive and significant role in mediating competence in employee performance.

\section{CONCLUSION}

The results of this study indicate that (1) Competence has a positive and significant effect on organizational commitment at PT. Bali Tangi Spa Production. This result means that the more competency increases, the organizational commitment will also increase. (2) Competence has a positive but not significant effect on employee performance at PT. Bali Tangi Spa Production. This means that even though competence increases, it does not affect the overall state of employee performance. (3) Organizational commitment has a positive and significant effect on the performance of the employees of PT. Bali Tangi Spa Production. These results illustrate that the stronger organizational commitment, employee performance also increases. (4) Organizational commitment is a perfect mediation (full mediation) in mediating competence on employee performance at PT. Bali Tangi Spa Production. These results mean 
that organizational commitment is very capable of supporting the relationship of competence on employee performance, meaning that the effect of competence on employee performance is able to be conveyed properly by organizational commitment.

\section{REFERENCES}

Achmad, S. R. (2003). Kualitas Sumber Daya Manusia. Jakarta: PT Gramedia Pustaka Utama.

Alexandri, M. B., Pragiwani, M., \& Yuswardi. (2019). The Effect of Competence and Discipline of Work on Motivation and Its Impact on Performance of Forensic Checkers at Puslabfor Bareskrim Indonesia National Police (POLRI). Academy of Strategic Management Journal, 18(4), 1-13. Retrieved from https://search.proquest.com/ docview $/ 2294437784$ ?pq-origsite $=$ gscholar

Carmeli, A., \& Freund, A. (2004). Work Commitment, Job Satisfaction, and Job Performance: An Empirical Investigation. International Journal of Organization Theory and Behavior, 6(4), 289-309. Retrieved from https:// pdfs.semanticscholar.org/ f93d/6fecee21 ce101da05f99db571a32449c3 be3.pdf

Dessler, G. (2013). Manajemen Sumber Daya Manusia (9th ed.). Jakarta: Kelompok Gramedia.

Edison, E., Anwar, Y., \& Komariyah, I. (2016). Human resource management: Strategies and changes in order to improve employee and organizational performance. Bandung: Alfabeta.

Fauzan, A. H., \& Sumiyati. (2015). Kinerja Karyawan (Studi pada Karyawan PT . Bank Mandiri Tbk. Area Cirebon (Yos Sudarso). Universitas Pendidikan Indonesia.

Ghozali, I. (2011). Aplikasi Analisis Multivariate Dengan Program SPSS. Semarang: BP Universitas Diponegoro.

Gibson, J. L. (1997). Organisasi. Jakarta: Erlangga.

Goel, R., Sahai, S., Vinaik, A., \& Garg, V. (2019). Moving from cash to cashless economy: - A study of consumer perception towards digital transactions. International Journal of Recent Technology and Engineering, 8(1), 1220-1226. Retrieved from https:// www.ijrte.org/wp-content/uploads/papers/ v8i1/A9218058119.pdf

Greenberg, J., \& Baron, R. A. (2003). Behavior in organizations: understanding and managing the human side of work \%. Upper Saddle River, NJ: Prentice Hall (8th ed.). Singapore: Upper Saddle River, NJ: Prentice Hall. Retrieved from https://archive.org/ details/behaviorinorgani00gree

Gupta, A. (2013). Essays on Spatial Autoregressive Models with Increasingly Many Parameters.
The London School of Economics and Political Science.

Hair Jr, J. F., Black, W. C., Babin, B. J., \& Anderson, R. E. (2010). Multivariate Data Analysis (7th ed.). United States: Pearson.

Hersey, P., \& Blanchard, K. H. (1993). Management for Organizational Behavior (6th ed.). Singapore: Prentice hall.

Hutapea, P., \& Thoha, N. (2008). Kompetensi Plus. Jakarta: PT Gramedia Pustaka Utama.

Izzati, U. A., Suhariadi, F., \& Hadi, C. (2016). The Role of Self Competence on Affective Organizational Commitment of Vocational High School Temporary Teachers. In F. L. Dembowski, C.-J. Shieh, S. Ivanov, A. M. Kamaruddeen, A. E. Simon, A. Maritz, ... C. C. Chiang (Eds.), The International Journal of Organizational Innovation (Vol. 8, p. 133). USA: IJOI. Retrieved from http:// www.ijoi-online.org/

Jogiyanto, \& Abdillah, W. (2009). Konsep dan Aplikasi PLS (Partial Least Square) untuk Penelitian Empiris. Yogyakarta: BPFE.

Khattak, M. S., Mustafa, U., Rehman, A. U., \& Khattak, I. U. (2016). Impact of Management Competencies and Complexities on Performance in Public Sector Infrastructure Projects of Pakistan. NUML International Journal of Business \& Management, 11(2), 12-34. Retrieved from https://www.researchgate.net/ publication/335755842_Impact_of_Manage ment Competencies and Complexities on Performance in Public Sector_Infrastructur e_Projects_of_Pakistan

Khoreva, V., Vaiman, V., \& Zalk, M. Van. (2017). Talent Management Practice Effectiveness: Investigating Employee Perspective. Employee Relations: The International Journal, 39(1), 19-33. https:// doi.org/10.1108/ER-01-2016-0005

Kurniasari, I. C., Thoyib, A., \& Rofiaty. (2018). Peran Komitmen Organisasional Dalam Memediasi Pengaruh Kompetensi, Pelatihan Dan Budaya Organisasi Terhadap Kinerja Perawat. MIX: Jurnal Ilmiah Manajemen, 8 (2), 352-371. https://doi.org/ dx.doi.org/10.22441/mix.2018.v8i2.010 352

Malau, A. G., Barasa, L., \& Sumali, B. (2019). Effect of Competence and Ship Crew Discipline on Performance PT . Myclin Express Offshore. International Review of Management and Marketing, 9(5), 30-37. Retrieved from https://doi.org/10.32479/ irmm. 8530

Marjito, P. (2014). Pengaruh Kompetensi Guru dan Perilaku Individu terhadap Komitmen Organisasional dan Dampaknya terhadap Kinerja Guru Pengelola Kurikulum di SMP Kota Singkawang. Masters thesis, Universitas Terbuka. Retrieved from http:// repository.ut.ac.id/243/

Mathis, R. L., \& Jackson, J. H. (2006). Human 
Resources Management (10th ed.). Jakarta: Salemba Empat.

Meswantri, M., \& Awaludin, A. (2018). Determinant of Employee Engagement and its Implications on Employee Performance. International Review of Management and Marketing, 8(3), 36-44. Retrieved from https://www.econjournals.com/index.php/ irmm/article/view/6365

Meyer, J. P., Allen, N. J., \& Smith, C. A. (1993). Commitment to Organizations and Occupations: Extension and Test of a ThreeComponent Conceptualization. Journal of Applied Psychology, 78(4), 538-551. https:// doi.org/10.1037/0021-9010.78.4.538

Rantesalu, A., Mus, A. R., Mapparenta, \& Arifin, Z. (2016). The Effect of Competence, Motivation and Organizational Culture on Employee Performance : the Mediating Role of Organizational Commitment. Quest Journals: Journal of Research in Business and Management, 4(9), 8-14. Retrieved from https://ideas.repec.org/p/osf/inarxi/ m7wqs.html

Saputri, E. D., \& Muhsin. (2018). Peran Komitmen Organisasi Dalam Memediasi Pengaruh Variabel Keteladanan Pemimpin, Kompetensi Perangkat Desa, Dan Budaya Organisasi Terhadap Kinerja. Economic Education Analysis Journal, 7(3), 1130 1147. Retrieved from https:// doi.org/10.15294/eeaj.v7i3.28345

Sentono, S. (1999). Manajemen Kepegawaian. Bandung: Penerbit Alumni Bandung.

Setyaningrum, R. P., Setiawan, M., Surachman, S., \& Irawanto, D. W. (2017). Employees Performance; Leadership, Organizational Commitment and Trust. International Economic Society, 11(2), 281-288. Retrieved from http://jemp.org/volume-11issue-2-281-288/

Soekidjan. (2009). Manajemen Sumber Daya Manusia. Jakarta: Bumi Aksara.

Solimun. (2011). Analisis Variabel Moderasi dan Mediasi. Program Studi Statistika FMIPA Universitas Brawijaya. Malang.

Spencer Jr, L. M., \& Spencer, S. M. (2007). Competence at Work: Models for Superrior. Canada: John Wiley \& Son.

Sugiyono. (2004). Metode Penelitian. Bandung: Alfabeta.

Sugiyono. (2012). Metode Kuantitative and Kualitative and $R \& D$. Bandung: Alfabeta.

Sutrisno, E. (2011). Manajemen Sumber Daya Manusia. Jakarta: Kencana.

Tehseen, S., Qureshi, Z. H., \& Ramayah, T. (2018). Impact of Network Competence on Firm's Performances Among Chinese And Indian Entrepreneurs: A Multigroup Analysis. International Journal of Entrepreneurship, 22(2), 1-14. Retrieved from https:// www.abacademies.org/articles/impact-of- network-competence-on-firms-performances -among-chinese-and-indian-entrepreneurs-amultigroup-analysis-7368.html

Trismiyanto, H. H., Sule, E. T., Joeliaty, \& Yunizar. (2018). The Influence of Entrepreneurial Competence and Innovation on Performance Mediated by Opportunities on Small Handicraft Industry Craftsmen in West Java. Academy of Strategic Management Journal, 17(6). Retrieved from https://www.abacademies.org/articles/theinfluence-of-entrepreneurial-competenceand-innovation-on-performance-mediatedby-opportunities-on-small-handicraftindustry-c-7666.html

Wang, Q., Jiang, Y., Weng, Q., \& Wang, Q. (2019). A meta-analysis of the relationship between occupational commitment and job performance. Social Behavior and Personality an International Journal, 47(8), 1-15. https://doi.org//doi.org/10.2224/ sbp. 8232

Yuliantini, P. A., Astika, I. B. P., \& Badera, D. N. (2017). Pengaruh Kompetensi Sumber Daya Manusia, Motivasi Dan Lingkungan Kerja Pada Komitmen Organisasi Dan Implikasinya Pada Kinerja Pengurus Barang. E-Jurnal Ekonomi Dan Bisnis Universitas Udayana, 6(10), 3697-3730. Retrieved from https://doi.org/10.24843/ EEB.2017.v06.i10.p10 